\title{
Evaluasi Management Support pada Pengelolaan Obat di RSUD Kabupaten Ngawi
}

\author{
Evaluation of Management Support in Drug Management in RSUD Ngawi \\ District
}

\author{
Fita Dewi Yuniarti1*, Satibi², Tri Murti Andayani2 \\ ${ }^{1}$ Magister Manajemen Farmasi, Program Pascasarjana, Program Studi Ilmu Farmasi, Fakultas \\ Farmasi, Universitas Gadjah Mada \\ 2 Fakultas Farmasi, Universitas Gadjah Mada \\ Corresponding author: Fita Dewi Yuniarti: Email: harfita84@gmail.com \\ Submitted: 04-12-2019 Revised: 30-12-2019 Accepted: 30-12-2019
}

\begin{abstract}
ABSTRAK
Pengelolaan obat yang efektif dan efisien di instalasi farmasi rumah sakit meliputi tahap seleksi, pengadaan, distribusi dan penggunaan yang didukung oleh manajemen pendukung (management support) yang terdiri dari perencanaan administrasi, organisasi, sumber daya manusia, sistem informasi. Tujuan penelitian ini untuk mengetahui gambaran management support terhadap pengelolaan obat di Instalasi Farmasi RSUD Kabupaten Ngawi. Penelitian ini bersifat deskriptif menggunakan metode wawancara dan telaah dokumen. Data kuantitatif diambil secara retrospektif (tahun 2018); dan data kualitatif diperoleh dari wawancara dengan informan yang dipilih secara purposive sampling. Data hasil penelusuran dokumen dan wawancara diklasifikasikan menjadi 2 kelompok yaitu data kualitatif dan data kuantitatif. Data kualitatif berupa hasil wawancara disajikan dalam bentuk tekstual berupa narasi. Data kuantitatif dibandingkan dengan standar, kemudian disajikan dalam bentuk tabel. Dari hasil penelitian ini menunjukkan perencanaan dan administrasi pada persentase kesesuaian jumlah permintaan dan perencanaan 103,18\%; persentase stok obat mati 0,4\%; persentase obat ED 0,36\%. dari manajemen organisasi, sudah terdapat struktur organisasi yang jelas sesuai dengan tugas, pokok dan fungsinya. Dari manajemen sumber daya manusia, memerlukan penambahan SDM apoteker. Dari manajemen sistem informasi: SIM yang ada hanya lokal untuk instalasi farmasi. Dari hasil penelitian ini menunjukkan bahwa pengelolaan obat di IFRS RSUD Kabupaten Ngawi belum efisien, karena belum didukung sepenuhnya oleh management support yang baik.
\end{abstract}

Kata kunci: management support; rumah sakit

\begin{abstract}
Effective and efficient drug management in hospital pharmacy departement including the selection, procurement, distribution and use phases supported by management support which consists of administrative planning, organization, human resources, information systems. The purpose of this study was to determine the description of management support for drug management in the Pharmacy Departement of Ngawi District Hospital. This research is descriptive using the interview method and document review. Quantitative data were collected retrospectively (2018); and qualitative data obtained from interviews with informants chosen by purposive sampling. Document search results and interview data are classified into 2 groups, namely qualitative data and quantitative data. Qualitative data in the form of interviews are presented in textual form in the form of narration. Quantitative data is compared with the standard, then presented in tabular form. The results of this study indicate planning and administration on the suitability percentage of the number of requests and planning 103.18\%; percentage of dead drug stock $0.4 \%$; the percentage of ED drugs is $0.36 \%$. from the management of the organization, there is already a clear organizational structure in accordance with its tasks, focus and functions. From human resource management, it still requires the addition of pharmacist. From the management of information systems: SIM are only local for pharmaceutical departement. From the results of this study indicate that the management of drugs in IFRS Ngawi District Hospital is not efficient, because it has not been fully supported by good management support.
\end{abstract}


Keywords: management support; hospital.

\section{PENDAHULUAN}

Peraturan Menteri Kesehatan Nomor 58 Tahun 2014 tentang Standar Pelayanan Kefarmasian di Rumah Sakit, menyebutkan bahwa penyelenggaraan pelayanan kefarmasian dirumah sakit harus menjamin ketersediaan sediaan farmasi, alat kesehatan, dan bahan medis habis pakai yang aman, bermutu, bermanfaat dan terjangkau (Depkes RI, 2014). Kegiatan pengelolaan obat dirumah sakit meliputi tahap seleksi, pengadaan, pendistribusian dan penggunaan (Quick et al., 1997). Keempat tahap tersebut harus didukung oleh manajemen pendukung (management support), agar terwujud pengelolaan obat yang efektif dan efisien (Quick et al., 2012).

Evaluasi pengelolaan obat telah dilakukan di beberapa rumah sakit oleh peneliti sebelumnya antara lain oleh Ulfah dkk (Djatmiko et al., 2008), yang melakukan evaluasi pengelolaan obat di RSUD Muntilan Magelang tahun 2015-2016; Djatmiko dkk, melakukan evaluasi pengelolaan obat di instalasi farmasi RSUP Dr. Kariadi Semarang tahun 2007; Ihsan dkk (Ihsan et al., 2014), melakukan evaluasi pengelolaan obat di instalasi farmasi RSUD Kabupaten Muna tahun 2014; Wati dkk (Fakhriadi et al., 2008), melakukan evaluasi pengelolaan obat di RSUD Karel Sadsuitubun Kabupaten Maluku Tenggara tahun 2012; Fakhriadi dkk, melakukan analisa pengelolaan obat di RS PKU Muhammadiyah Temanggung tahun 2006-2008 dilengkapi dengan gambaran managemen support.

Jumlah kunjungan di RSUD Kabupaten Ngawi terus mengalami peningkatan setiap tahunnya, merupakan rumah sakit pemerintah tunggal yang ada sehingga menjadi rumah sakit rujukan untuk seluruh puskesmas/pasien yang ada di Kabupaten Ngawi. Namun berdasarkan informasi yang diperoleh dari Kepala IFRS, bahwa tingkat keterjaringan resep di instalasi farmasi belum $100 \%$. Beberapa pasien masih ada yang memilih untuk menebus resep diapotek luar rumah sakit. Penyebabnya adalah pelayanan resep yang lama sehingga pasien harus menunggu waktu berjam-jam untuk mendapatkan obat. Hal ini tentunya akan memberikan dampak yang negatif bagi pendapatan rumah sakit, mengingat sebanyak
$40 \%$ dari keseluruhan pendapatan rumah sakit berasal dari bisnis farmasi RS.

Penelitian ini dilakukan untuk melihat gambaran management support dalam pengelolaan obat pada periode tahun $2018 \mathrm{di}$ Instalasi Farmasi RSUD Kabupaten Ngawi. Hasil pengukuran management support dapat dijadikan sebagai fungsi evaluasi dari pihak IFRS dan manajemen terkait, untuk pengambilan keputusan dalam pengelolaan obat.

\section{METODOLOGI}

Penelitian dilaksanakan pada bulan Oktober-November 2019 di Instalasi Farmasi RSUD Kabupaten Ngawi. Penelitian ini merupakan penelitian deskriptif. Data dikumpulkan melalui wawancara dan telaah dokumen secara retrospektif dengan memakai data sekunder. Sumber informan sekaligus subyek dalam penelitian adalah Direktur, Kepala Instalasi Farmasi, Apoteker Penanggung jawab dan petugas gudang farmasi. Variabel penelitian yaitu terkait management support dalam pengelolaan obat yang meliputi manajemen perencanaan dan administrasi; manajemen organisasi; manajemen sumber daya manusia; serta manajemen sistem informasi.

Data primer diperoleh dari wawancara mendalam kepada informan dengan menggunakan panduan wawancara. Informan dipilih secara purposive sampling Wawancara bertujuan untuk mengidentifikasi dukungan management support dalam pengelolaan obat. Data sekunder diperoleh dari penelusuran dokumen-dokumen tahun 2018 terkait pengelolaan obat seperti data usulan kebutuhan obat periode tahun 2018; data penerimaan obat tahun 2018; kartu stok obat; data stok opname IFRS tiap semester di tahun 2018; laporan persediaan akhir IFRS tahun 2018.

Data hasil penelusuran dokumen dan wawancara diklasifikasikan menjadi 2 kelompok yaitu data kualitatif dan data kuantitatif. Data kualitatif berupa hasil wawancara disajikan dalam bentuk tekstual berupa narasi. Data kuantitatif dibandingkan dengan nilai standar indikator yang telah ditetapkan yaitu indikator Depkes (2008); Pudjaningsih(1996); dan modifikasi metode 
Tabel I. Kesesuaian jumlah permintaan dan perencanaan di IFRS RSUD Kabupaten Ngawi tahun 2018

\begin{tabular}{lc}
\hline & RSUD Kabupaten Ngawi \\
\hline Jumlah item obat yang diminta & 162 \\
Jumlah item obat yang direncanakan & 157 \\
Persentase kesesuaian jumlah permintaan dan perencanaan & 103,18 \\
\hline
\end{tabular}

Tabel II. Persentase stok mati obat di RSUD Kabupaten Ngawi tahun 2018

\begin{tabular}{cc}
\hline & RSUD Kabupaten Ngawi \\
\hline Jumlah item obat stok mati & 35 \\
Jumlah total obat & 8028 \\
Persentase stok obat mati & 0,4 \\
\hline
\end{tabular}

Delphi(2019) (Satibi et al., 2019); kemudian disajikan dalam bentuk tabel.

\section{HASIL DAN PEMBAHASAN \\ Manajemen perencanaan dan administrasi}

Perencanaan yang tepat merupakan hal yang pokok dalam pengelolaan obat. Dasar dari perencanaan yang tepat adalah kegiatan administrasi/pencatatan yang tertib. Langkah untuk menilai pengaruh manajemen perencanaan dan administrasi, dapat dilihat pada indikator kesesuaian jumlah permintaan dan perencanaan; stok obat mati; dan obat kadaluarsa.

\section{Kesesuaian jumlah permintaan dan perencanaan}

Dari tabel I terlihat bahwa hasil persentase dari indikator kesesuaian jumlah permintaan dan perencanaan sebesar 103,18\%. Nilai ini lebih besar dari standarnya yaitu $100 \%$, yang menunjukkan belum efisiennya pengelolaan obat. Penyebabnya adalah kegiatan administrasi kartu stok obat yang masih manual, sehingga mempersulit petugas dalam menyusun rencana kebutuhan obat tahun berikutnya, akibatnya ada beberapa item obat yang menyimpang dari yang direncanakan; dan adanya usulan item obat baru yang tidak tercatat/terdokumentasi dengan baik untuk memenuhi kebutuhan instalasi baru. Menurut penelitian (Triana, 2014) bahwa pencatatan dan pelaporan merupakan salah satu sumber yang digunakan dalam perencanaan, jika tidak akurat maka perencanaan yang dilakukan tidak optimal.

\section{Stok obat mati}

Manajemen perencanaan dan administrasi pada pengelolaan obat, dapat juga dilihat dari indikator stok obat yang mati. Tabel II menunjukkan masih adanya item obat yang stoknya mati di Instalasi Farmasi RSUD Kabupaten Ngawi sejumlah 35 item obat atau $0,4 \%$ pada tahun 2018. Diperoleh persentase stok obat mati di Rumah Sakit Ortopedi sebesar 3,33\% dan RSU Haji Surabaya sebesar 39\% (Sasongko et al., 2014; Mellen et al., 2013). Stok obat mati menunjukkan berapa jumlah item obat yang tidak ada transaksi baik pemasukan dan pengeluaran obat selama setahun (Satibi, 2014). Data ini dapat diperoleh dari data mutasi obat Instalasi Farmasi RSUD Kabupaten Ngawi tahun 2018. Kondisi ini terjadi dikarenakan kegiatan administrasi dalam menghitung jumlah persediaan akhir yang tidak tepat, sehingga dalam membuat perencanaan kebutuhan obat menyimpang dari kebutuhan sebenarnya, sehingga kemungkinan terjadinya penumpukan persediaan farmasi di gudang.

\section{Obat Kadaluarsa}

Kenyataan di lapangan, masih ditemukan obat kadaluarsa di IFRS RSUD Kabupaten Ngawi, seperti di tabel IV. Berdasarkan hasil wawancara dengan Kepala IFRS, hal ini disebabkan karena pencatatan ED obat dikartu stok masih manual dan belum dilakukan rekapitulasi terkait obat yang akan ED dalam waktu terdekat, petugas gudang dengan jumlah tenaga yang terbatas kesulitan untuk mengecek ED obat satu persatu secara manual. 


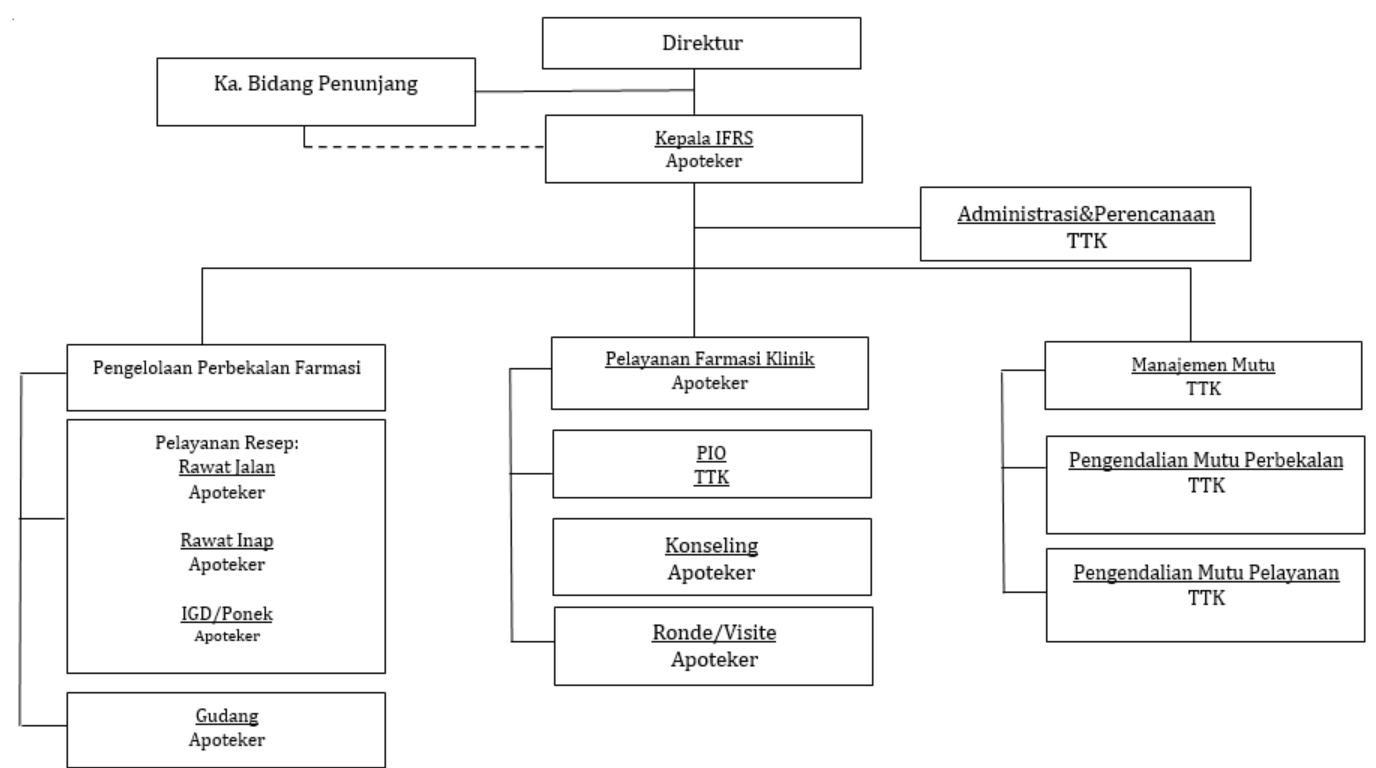

Gambar 1. Bagan Struktur Organisasi IFRS RSUD Kabupaten Ngawi

Hal ini dapat diatasi apabila kegiatan administrasi dilakukan secara tertib dan rutin setiap bulan, dimana dilakukan pengecekan kadaluarsa obat serta didokumentasikan dalam bentuk rekapitulasi.

\section{Organisasi}

Penyelenggaraan standar pelayanan kefarmasian di rumah sakit harus didukung oleh pengorganisasian yang berorientasi kepada keselamatan pasien dan standar prosedur operasional (Kementrian Kesehatan RI, 2016). Pengorganisasian harus menggambarkan uraian tugas, fungsi dan tanggung jawab serta hubungan koordinasi yang harmonis, yang terjalin dengan baik, didalam maupun di luar kegiatan pelayanan kefarmasian yang ditetapkan oleh pimpinan rumah sakit (Depkes RI, 2014).

Instalasi Farmasi RSUD Kabupaten Ngawi sudah mempunyai struktur organisasi yang jelas sesuai dengan kebutuhan. Ada kegiatan pengelolaan obat; pelayanan farmasi klinik serta pengendalian mutu pelayanan kefarmasian. Masing-masing bagan, dalam pelaksanaannya dilakukan oleh tenaga kefarmasian yang mempunyai kemampuan, keterampilan, dan skill sesuai dengan tanggung jawabnya. Bagan struktur organisasi IFRS RSUD Kabupaten Ngawi dapat dilihat pada gambar 1 .

Berdasarkan hasil wawancara dengan Kepala IFRS bahwa struktur organisasi yang ada di IFRS RSUD Kabupaten Ngawi sudah berjalan dengan baik sesuai dengan tugas, pokok dan fungsinya. Hal ini dibuktikan dengan terjalinnya komunikasi yang baik dengan dokter penulis resep terkait obat yang kosong/akan ED, dimana penulis resep bersedia untuk obatnya diganti dengan obat lain yang sejenis; komunikasi dengan bidang keuangan juga terjalin baik, terutama mengenai alokasi dana anggaran belanja obat yang kurang, maka bidang keuangan akan mencarikan alokasi dana yang bisa digeser dari unit manapun, untuk bisa digunakan oleh IFRS. Menurut hasil penelitian (Rumbay et al., 2015), perencanaan kebutuhan obat yang baik dan tepat, akan tercapai jika ada koordinasi yang baik antar bidang.

\section{Sumber daya Manusia}

Pemenuhan sumber daya manusia (SDM) merupakan hal yang penting bagi suatu perusahaan (instalasi farmasi). Kelebihan tenaga menyebabkan beban tenaga menjadi besar dan tidak efisien dalam pengelolaan keuangan (Beswick et al., 2010), sedangkan kekurangan tenaga akan meningkatkan beban kerja SDM yang dapat mempengaruhi kualitas pelayanan (Ilyas, 2011). Ketersediaan SDM farmasi disesuaikan dengan kebutuhan rumah sakit. Perencanaan SDM perlu dibuat dengan tepat sesuai kebutuhan, dimana dihitung berdasarkan beban kerja (Depkes RI, 2009). 
Tabel III. Tenaga kefarmasian di IFRS RSUD Kabupaten Ngawi

\begin{tabular}{|c|c|c|c|}
\hline No & Jabatan & Pendidikan & Jumlah \\
\hline 1 & Kepala Instalasi Farmasi & Apoteker & 1 \\
\hline \multirow[t]{8}{*}{2} & Apoteker Penanggung Jawab & & \\
\hline & a. Gudang & Apoteker & 1 \\
\hline & b. Rawat Jalan* & Apoteker & 1 \\
\hline & c. Rawat Inap* & Apoteker & 1 \\
\hline & d. IGD* & Apoteker & 1 \\
\hline & e. Pelayanan Farmasi Klinik & Apoteker & 1 \\
\hline & f. Konseling* & Apoteker & 1 \\
\hline & g. Ronde/Visite* & Apoteker & 1 \\
\hline \multirow[t]{6}{*}{3} & Asisten Apoteker & & \\
\hline & a. Administrasi Perencanaan* & Diploma-3 Farmasi & 1 \\
\hline & b. $\mathrm{PIO}^{*}$ & Diploma-3 Farmasi & 1 \\
\hline & c. Manajemen Mutu* & Diploma-3 Farmasi & 1 \\
\hline & d. Pengendalian Mutu Perbekalan* & Diploma-3 Farmasi & 1 \\
\hline & e. Pengendalian Mutu Pelayanan* & Diploma-3 Farmasi & 1 \\
\hline \multirow[t]{7}{*}{4} & Asisten Apoteker & & \\
\hline & a. Rawat Jalan & Diploma-3 Farmasi & 6 \\
\hline & & Sarjana Farmasi & 1 \\
\hline & & SMF & 1 \\
\hline & b. Rawat Inap & Diploma-3 Farmasi & 5 \\
\hline & & SMF & 2 \\
\hline & c. IGD & Diploma-3 Farmasi & 4 \\
\hline \multirow[t]{6}{*}{5} & Juru Racik & & \\
\hline & a. Rawat Inap & Sarjana & 2 \\
\hline & & Umum & 1 \\
\hline & b. Rawat Jalan & Sarjana & 5 \\
\hline & c. IGD & Sarjana & 2 \\
\hline & & Umum & 1 \\
\hline
\end{tabular}

Keterangan: tanda* artinya petugas farmasi juga merangkap sebagai pelaksana di pelayanan rawat inap/rawat jalan/IGD.

SDM yang dimiliki oleh IFRS RSUD Kabupaten Ngawi berjumlah 42 orang terdiri dari tenaga kefarmasian (apoteker dan tenaga teknis kefarmasian) dan juru racik (lihat tabel.3) Tenaga kefarmasian bekerja sesuai jadwal jaga shift pagi, siang dan malam. Jumlah tenaga kefarmasian yang ada sekarang sudah ada penambahan dibandingkan tahun-tahun sebelumnya, akan tetapi masih kurang jumlahnya untuk mendukung pelaksanaan pelayanan kefarmasian. Hal ini terlihat pada pelayanan resep pasien di unit rawat jalan. Ratarata waktu tunggu pelayanan resep masih melebihi dari standarnya, dimana untuk obat racikan memerlukan waktu tunggu 65 menit dan obat jadi memerlukan waktu tunggu 35,69 menit. Nilai standar untuk waktu tunggu pelayanan resep obat racikan adalah kurang dari 60 menit, dan untuk obat kurang dari 30 menit (Depkes RI, 2008). Berdasarkan hasil pengamatan, bahwa apoteker yang bekerja di unit rawat jalan ada 2 orang, dimana seorang apoteker bertugas untuk melakukan kontrol/pengecekan pada obat yang sudah diberikan etiket, sedangkan apoteker yang lain melakukan penyerahan obat beserta pemberian KIE (Konseling Informasi dan Edukasi) pada pasien. Kekurangan tenaga apoteker dibagian penyerahan obat membuat waktu tunggu pasien untuk mendapatkan obat akan semakin lama, karena setiap kali proses pemanggilan pasien, apoteker hanya mampu menyerahkan 6-8 lembar resep pasien. Kegiatan ini dilakukan berulang secara bergantian oleh 2 orang apoteker tersebut sampai jumlah pasien habis. 
Tabel IV. Persentase obat kadaluarsa RSUD Kabupaten Ngawi tahun 2018

\begin{tabular}{ll}
\hline & RSUD Dr.Soeroto Ngawi \\
\hline Nilai obat rusak dan kadaluarsa tahun 2018 & Rp. 7,123,829 \\
Nilai stok opname tahun 2018 & Rp. 2,001,263,251 \\
Persentase obat yang kadaluarsa dan rusak & $0,36 \%$ \\
\hline
\end{tabular}

Sumber: Laporan Persediaan Akhir Tahun 2018

Pengelolaan SDM di IFRS RSUD Kabupaten Ngawi, selama ini hanya menggunakan analisa jumlah resep. Hal ini akan mengakibatkan pemenuhan SDM akan selalu berbanding lurus dengan jumlah resep. Kenyataannya tenaga kefarmasian tidak hanya melakukan kegiatan pelayanan resep saja, tetapi juga melakukan kegiatan lainnya yang menunjang pelayanan kefarmasian. Pemenuhan SDM yang tidak mencukupi akan memberikan dampak beban kerja yang tinggi pada tenaga kefarmasian yang dapat menurunkan kualitas pelayanan (Harijanto et al., 2014). Beban kerja yang tinggi dapat meningkatkan potensi terjadinya kesalahan pengobatan (Verawaty et al., 2017). Usulan kebutuhan jumlah SDM di IFRS RSUD Kabupaten Ngawi dilakukan setiap akhir tahun, dikarenakan terkait jumlah anggaran untuk tahun berikutnya.

Hasil ini menunjukkan bahwa jumlah SDM yang ada belum cukup memenuhi kebutuhan untuk pelaksanaan kegiatan pengelolaan obat di IFRS RSUD Kabupaten Ngawi, sehingga perlu penambahan SDM dengan berdasarkan analisa beban kerja.

\section{Sistem Informasi}

Seiring dengan perkembangan jaman era digital 4.0, sudah saatnya rumah sakit untuk meninggalkan kegiatan administrasi secara manual dan berubah untuk menggunakan sistem informasi manajemen rumah sakit berbasis komputer. Kegiatan ini memerlukan dukungan yang besar dari direktur dan pihak manajemen rumah sakit, terkait alokasi dana anggaran. Sistem informasi manajemen berbasis komputer merupakan sarana pendukung yang sangat penting, bahkan bisa dikatakan mutlak untuk operasional rumah sakit.

Dalam kegiatan administrasi, dengan adanya SIM sudah tidak perlu menggunakan kartu stok manual, sehingga kegiatan pelaporan persediaan obat dapat terselesaikan dengan cepat, tepat dan akurat.
Indikator dalam pengelolaan obat yang dapat dipakai untuk menilai pengaruh management support khususnya SIM yaitu persentase obat kadaluarsa.

\section{Persentase obat kadaluarsa}

Tabel IV menunjukkan bahwa persentase obat kadaluarsa di IFRS RSUD Kabupaten Ngawi pada tahun 2018 sebesar 0,36\%. Adanya obat kadaluarsa ini dinilai masih kurang, yang menunjukkan belum efisiennya pengelolaan obat . Nilai obat kadaluarsa yang dapat diterima untuk instalasi farmasi rumah sakit berdasarkan indikator (Pudjaningsih, 1996) adalah 0\%. Berdasarkan hasil wawancara dengan Kepala IFRS dan petugas gudang farmasi, penyebab adanya obat kadaluarsa adalah SIM yang dipakai belum bisa memunculkan item obat apa saja yang akan ED dalam waktu terdekat dan petugas gudang merasa kesulitan jika harus mengecek manual ED item obat satu persatu dengan jumlah item obat di IFRS sebanyak 1800 item.

Instalasi Farmasi RSUD di Kabupaten Ngawi sudah menggunakan SIM, akan tetapi belum terintegrasi dengan seluruh unit yang ada di rumah sakit. SIM yang dipakai masih lokal, hanya untuk IFRS saja. SIM ini belum bisa memenuhi semua kebutuhan instalasi farmasi terkait pengelolaan obat. Menurut penelitian (Rahmawatie E dan Santosa S, 2015), sistem informasi yang telah berfungsi dengan baik, dapat membantu dalam mengambil keputusan khususnya dalam perencanaan kebutuhan obat.

\section{KESIMPULAN}

Dari hasil penelitian ini menunjukkan manajemen perencanaan dan administrasi pada persentase kesesuaian jumlah permintaan dan perencanaan 103,13\%; persentase stok obat mati $0,4 \%$; persentase obat ED 0,36\%. Dari manajemen organisasi, sudah terdapat struktur organisasi yang jelas sesuai dengan tugas, pokok dan fungsinya, namun belum bekerja secara maksimal. Dari manajemen sumber daya 
manusia, masih memerlukan penambahan SDM apoteker terkait penyerahan obat ke pasien, supaya waktu tunggu pelayanan lebih cepat. Dari manajemen sistem informasi: SIM yang ada hanya lokal untuk instalasi farmasi dan belum memenuhi semua kebutuhan pelayanan farmasi. Dari hasil penelitian ini menunjukkan bahwa pengelolaan obat di IFRS RSUD Kabupaten Ngawi belum efisien, karena belum didukung sepenuhnya oleh management support yang baik.

\section{UCAPAN TERIMA KASIH}

Ucapan terima kasih kami sampaikan kepada PPSDMK atas bantuan biaya penelitian.

\section{DAFTAR PUSTAKA}

Depkes RI. Peraturan Menteri Kesehatan RI Nomor 58 tahun 2014 tentang Standar Pelayanan Kefarmasian di Rumah Sakit. 2014.

Quick JD, Rankin JR, Laing RO, O'Cornor RW. Managing Drug Supply, The Selection, Procurement, Distribution, and Use of Pharmaceutical, West Hartford, Connecticut. USA; 1997.

Quick JD, Rankin JR, Laing RO, O'Cornor RW. Managing Access to Medicine and Health Technology, Management Sciences for Health Inc. USA; 2012.

Djatmiko M, Rahayu E. Evaluasi Sistem Pengelolaan Obat di Instalasi Farmasi RSUP Dr. Kariadi Semarang Tahun 2007. JIFFK: Jurnal Ilmu Farmasi dan Farmasi Klinik. 2008;5(2):27-31.

Ihsan sunandar, sahid M. Evaluasi Pengelolaan Obat di Instalasi Farmasi RSUD Kabupaten Muna Tahun 2014. Pharmauho. 2015;1(2):23-28.

Fakhriadi A, Pudjaningsih D, Farmasi M. Drug Management Analysis In Pharmacy Departement of Pku Muhammadiyah Temanggung Hospital In Period 2006, 2007, And 2008. 2011;1(2):12.

Depkes RI. Keputusan Menteri Kesehatan RI Nomor 129/Menkes/SK/II/2008 Tentang Standar Pelayanan Minimal Di Rumah Sakit. Jakarta: Kementerian Kesehatan RI; 2008.

Satibi S, Rokhman MR, Aditama H. Developing Consensus Indicators to Assess Pharmacy Service Quality at Primary Health Centres in Yogyakarta, Indonesia. The Malaysian
Journal of Medical Sciences: MJMS. 2019;26(4):110.

Triana M. Evaluasi Perencanaan Obat Pelayanan Kesehatan Dasar (PKD) Di Gudang Farmasi Kabupaten Gunung Mas Tahun 2012, Tesis, M.Sc, Fakultas Kesehatan Masyarakat, Universitas Diponegoro, Semarang.; 2013.

Sasongko H, Satibi S, Fudholi A. Evaluasi Distribusi dan Penggunaan Obat Pasien Rawat Jalan di Rumah Sakit Ortopedi. Jurnal Manajemen dan Pelayanan Farmasi (Journal of Management and Pharmacy Practice). 2014;4(2):99-104.

Mellen R, Pudjirahardjo W. Faktor Penyebab dan Kerugian akibat Stock Out dan Stagnant obat di Unit Logistik RSU Haji Surabaya. Jurnal Administrasi Kesehatan Indonesia. 2013:1-9.

Satibi. Manajemen Obat Di Rumah Sakit. Yogyakarta: Gadjah Mada University Press; 2014.

Kementerian Kesehatan RI. Kementerian Kesehatan RI, 2016, Peraturan Menteri Kesehatan RI Nomor 72 Tahun 2016 Tentang Standar Pelayanan Kefarmasian Di Rumah Sakit, Kementerian Kesehatan RI, Jakarta.; 2016.

Rumbay I, Kandou G, Soleman T. Analysis of Drugs Planning in Health Office Southeast Minahasa Regency. JIKMU. 2015;5(2):469-478.

Beswick S, Hill P, Anderson M. Comparison of Nurse Workload Approaches. Journal of Nursing Management. 2010;18(5):592598.

Ilyas Y. Perencanaan SDM Rumah Sakit, Teori, Metoda Dan Formula Cetakan Ketiga. Depok: FKM UI; 2011.

Depkes RI. Undang Undang RI Nomor 51 Tentang Pekerjaan Kefarmasian. Jakarta: Kementerian Kesehatan RI; 2009.

Harijanto W, Moestopo FR, Indah YNN. Penentuan Kebutuhan Tenaga di RS HVA Toeloengredjo dengan Metode Workload Indicators of Staffing Need (WISN) untuk Efisiensi Sumber Daya Manusia. Jurnal Kedokteran Brawijaya. 2014;28(1):4146.

Verawaty V, Ramdani MI, Laksmitawati DR, Meidiawati C. Analysis of Pharmaceutical Staffing Needs in the Pharmacy Installation of Grha Permata Ibu Hospital 
Fita Dewi Yuniarti, et al

Depok 2016. Jurnal Manajemen Pelayanan Farmasi. 2017;7(2):65-74.

Rahmawatie E, Santosa S. Sistem Informasi
Perencanaan dan Pengadaan Obat di Dinas Kesehatan Kabupaten Boyolali. Jurnal Pseudocode. 2015:2-8. 